\title{
Pengaruh faktor budaya, faktor sosial, dan faktor pribadi terhadap keputusan pembelian
}

\author{
${ }^{1 *}$ Amalina Hudani \\ ${ }^{I}$ Fakultas Ekonomi, Universitas Sarjanawiyata Tamansiswa, Jalan Kusumanegara Yogyakarta 55165 \\ *e-mail korespondensi: amalinahudani0797@gmail.com
}

\begin{tabular}{l|l}
\hline \multicolumn{1}{c}{ Keywords } & \multicolumn{1}{c}{ Abstract } \\
\hline \hline $\begin{array}{l}\text { cultural factors, } \\
\text { social factors, } \\
\text { personal factors, } \\
\text { purchasing } \\
\text { decisions }\end{array}$ & $\begin{array}{l}\text { This study examines the Effect of Cultural Factors, Social Factors, and Personal } \\
\text { study were consumers who bought or consumed Sampoerna Mild cigarettes at the } \\
\text { Faculty of Economics, University of Sarjanawiyata Tamansiswa Yogyakarta. The } \\
\text { population in this study were respondents or students of the Faculty of Economics } \\
\text { who bought or consumed Sampoerna Mild cigarettes at the Faculty of Economics, } \\
\text { University of Sarjanawiyata Tamansiswa Yogyakarta. The method of data analysis } \\
\text { used was descriptive analysis using multiple linear regression, test, } R^{2} \text { test. Based } \\
\text { on the t-test this study shows that cultural factor variables (X1) have a significant } \\
\text { positive effect on purchasing decisions. Social variable (X2) does not have a } \\
\text { significant positive effect on purchasing decisions, while personal factor variables } \\
\text { (X3) have a significant positive effect on purchasing decisions. }\end{array}$ \\
\end{tabular}

\begin{tabular}{|c|c|}
\hline Kata Kunci & Abstrak \\
\hline $\begin{array}{l}\text { faktor budaya, } \\
\text { faktor sosial, faktor } \\
\text { pribadi, keputusan } \\
\text { pembelian }\end{array}$ & $\begin{array}{l}\text { Penelitian ini menguji Pengaruh Faktor Budaya, Faktor Sosial, dan Faktor Pribadi } \\
\text { terhadap Keputusan Pembelian Rokok Sampoerna Mild. Responden dari penelitian } \\
\text { ini adalah konsumen yang membeli atau mengonsumsi rokok Sampoerna Mild di } \\
\text { Fakultas Ekonomi Universitas Sarjanawiyata Tamansiswa Yogyakarta. Populasi } \\
\text { dalam penelitian ini adalah responden atau mahasiswa Fakultas Ekonomi yang } \\
\text { membeli atau atau mengkonsumsi rokok Sampoerna Mild di Fakultas Ekonomi } \\
\text { Universitas Sarjanawiyata Tamansiswa Yogyakarta. Metode analisis data yang } \\
\text { digunakan adalah analisis deskriptif dengan menggunakan regresi linier berganda, } \\
\text { uji t, uji } \mathrm{R}^{2} \text {. Berdasarkan uji-t penelitian ini menunjukkan bahwa variabel faktor } \\
\text { budaya (X1) berpengaruh positif signifikan terhadap keputusan pembelian. Variabel } \\
\text { sosial (X2) tidak berpengaruh positif signifikan terhadap keputusan pembelian, } \\
\text { sedangkan variabel faktor pribadi (X3) berpengaruh positif signifikan terhadap } \\
\text { keputusan pembelian. }\end{array}$ \\
\hline
\end{tabular}

\section{PENDAHULUAN}

Perilaku konsumen merupakan salah satu faktor penting dalam menentukan tingkat konsumsi rokok. Salah satu dimensi dari perilaku konsumen adalah prestis, dimana konsumen berusaha menunjukkan identitas atau citra dirinya melalui produk atau merek rokok yang dipilihnya. Menurut Schiffman dan Kanuk (2010) dalam peneletiannya 
menunjukkan bahwa konsumen juga memiliki berbagai macam citra yang melekat pada diri mereka sendiri. Faktor budaya, sosial dan pribadi sangat mempengaruhi keputusan pembelian produk rokok Sampoerna. Faktor budaya mempengaruhi keputusan pembelian produk rokok Sampoerna berdasarkan lingkungan masyarakat.

Faktor sosial mempengaruhi keputusan pembelian produk rokok Sampoerna tergantung dari pengaruh kelompok sosial bagi seseorang. Seseorang juga membeli dan mengonsumsi produk rokok Sampoerna sesuai peran dan statusnya di kelompok sosialnya. Faktor sosial seperti kelompok referensi, keluarga, serta peran sosial dan status juga memiliki pengaruh terhadap perilaku pembelian. Kelompok referensi (reference group) seorang adalah semua kelompok yang mempunyai pengaruh langsung (tatap muka) atau tidak langsung terhadap sikap atau perilaku orang tersebut. Keluarga adalah organisasi pembelian konsumen yang paling penting dalam masyarakat, dan anggota keluarga merepresentasikan kelompok referensi utama yang paling berpengaruh. Peran dan status, orang berpartisipasi dalam banyak kelompok-keluarga, klub, organisasi (Vu et al., 2020)

Faktor pribadi meliputi usia dan tahapan dalam siklus hidup pembeli, pekerjaan dan keadaan ekonomi, kepribadian dan konsep diri, serta gaya hidup dan nilai. Karena banyak dari karakteristik ini yang mempunyai dampak yang sangat langsung terhadap perilaku konsumen, penting bagi pemasar untuk mengikuti mereka seksama (Rahmad et al., 2020). Mengingat arti penting pelanggan sebagai kunci sukses usaha maka perusahaan harus dapat menjalin hubungan jangka panjang dengan pelanggan. Hubungan jangka panjang yang dimaksud bukan sekedar hubungan yang semu yaitu hubungan komunikasi satu arah dan bersifat sementara.

Untuk menarik minat konsumen para pelaku usaha dituntut untuk bisa memahami kebutuhan dan keinginan para konsumen dengan cara yang berbeda dari yang sebelumnya. Dalam hal ini, seorang pemasar perusahaan harus teliti dalam membaca dan meramalkan fenomena-fenomena atas perubahan-perubahan yang berlaku pada konsumen saat ini untuk dapat digunakan sebagai informasi dan sebuah referensi penting ketika menyusun sebuah strategi pemasaran dalam rangka mendapatkan dan mempertahankan serta nilai perusahaannya dan bagaimana kemudian mereka bisa bertahan (survive) atau bahkan sampai pada kondisi puncak yaitu memenangkan pasar (Kumar et al., 2020).

Saat ini zaman sudah berubah, demikan pula arus globalisasi semakin maju dan berkembang sehingga dapat merubah tatanan norma yang berlaku. Begitu pula anggapan terhadap perokok dipandang suatu hal yang negatif. Akan tetapi melihat perubahan zaman sekarang ini anggapan ini tentu saja sudah terbalik, malahan kaum remaja dan orang dewasa yang merokok sudah dianggap trend, budaya, maupun gaya hidup khususnya bagi yang tinggal di kota-kota besar (Uguy et al., 2019).

Aktivitas merokok oleh sebagian masyarakat dianggap sebagai kebiasaan yang bisa dilakukan dimana saja. Karena merokok dianggap sebagai hak seseorang untuk melakukannya. Tetapi yang perlu disadari pula adalah adanya hak orang lain yang tidak merokok untuk mendapatkan kebebasan dari asap rokok dan terhindar dari bahaya akibat rokok sebagai rokok pasif (Sari et al., 2019). 
Informasi tentang bahaya merokok terhadap kesehatan sudah banyak. Pada kenyataannya jutaan remaja setiap tahun mulai merokok sekitar $85 \%$. remaja yang merokok akan tetap menjadi perokok pada usia dewasa. Kecenderungan remaja yang mencoba merokok akan menjadi perokok tetap sangatlah besar. Rokok mengandung 3 bahan utama yang berdampak bagi kesehatan, yaitu tar, nikotin, dan karbon monoksida. Meski sekarang tersedia rokok yang terdapat kandungan tar dan nikotin yang rendah, akan tetapi tidak ada rokok yang aman bagi kesehatan. Dampak buruk rokok pada berokok tidak hanya sebatas perokok saja, tetapi juga pada orang disekitarnya. Orang-orang disekitar banyak yang menjadi perokok pasif. Di Amerika sekitar 4.000 orang perokok pasif meninggal setiap tahun karena kanker paru (Samsuridjal, 2009).

Hal ini dikaitkan dengan suatu pengambilan keputusan yang dilakukan oleh konsumen dalam melakukan pembelian suatu produk rokok. karena diawali oleh adanya kesadaran atas pemenuhan kebutuhan dan keinginan. Keputusan pembelian produk rokok juga dipengaruhi faktor pribadi yang terdiri dari umur, keadaan ekonomi, gaya hidup, dan kepribadian (Wahyuni \& Bachri, 2020). Segmen pasar dan target pasar sasaran produk rokok di Yogyakarta sebagian besar adalah pelajar dan mahasiswa. Karena Yogyakarta merupakan kota pelajar yang setiap tahunnya banyak didatangi mahasiswa dari berbagai penjuru tanah air bahkan mancanegara. Adat dan kebudayaan yang berbeda-beda secara otomatis bercampur dan mempengaruhi gaya hidup masyarakatnya. Demikian pula dari cara mengonsumsi produk-produk yang ditawarkan, seperti halnya rokok Sampoerna Mild yang merupakan suatu produk yang sudah banyak dikonsumsi oleh para masyarakat, dan salah satu konsumen yang termasuk didalamnya adalah mahasiswa.

Sampoerna Mild adalah perintis rokok Mild di Indonesia sejak awal tahun 90 an. Perusahaan ini telah bekerja keras untuk mempromosikan dan mengedukasi pasar tentang kelebihan rokok Samopoerna Mild. Hasilnya tidak mengecewakan, rokok Sampoerna Mild mendapat respon yang bagus dan pasarannya terus berkembang. Pada awalnya, penjualan rokok low tar dari HM Sampoerna tidak begitu signifikan hingga tiga tahun sejak peluncuran perdananya. Penjualan rokok Sampoerna Mild masih tertinggal jauh dibanding kategori lainnya. Dari total produksi nasional yang sebesar 152,7 miliar batang Sampoerna Mild hanya memberi kontribusi 0,33\% atau 0,5 miliar batang dibandingkan dengan SKM regular yang produksinya mencapai 94,2 miliar batang, atau 61,69\% total produksi rokok nasional.

PT. HM sampoerna Tbk. Sebagai pemegang merk Sampoerna Mild berusaha berinovasi dengan berbagai cara agar penjualan rokok Sampoerna di industri rokok nasional dapat meningkat. Pada tahun 1994 penjualan rokok Sampoerna Mild melonjak tiga kali lipat dari sebelumnya yang hanya 18 juta batang per bulan menjadi 54 juta batang per bulan. Dan seiring berjalannya waktu penjualan rokok Sampoerna Mild terus beranjak naik.

\section{TEORI DAN HIPOTESIS}

\section{Faktor Budaya}

Suryani (2012) berpendapat bahwa budaya sebagai komplek yang menyeluruh yang mencakup pengetahuan, keyakinan, seni, hukum, moral, kebiasaan, dan kapabilitas lainnya serta kebiasaan-kebiasaan yang dikuasai oleh individu sebagai anggota masyarakat. Dalam 
konteks pemahaman budaya dan pengaruhnya terhadap perilaku konsumen, budaya didefinisikan sebagai keseluruhan dari keyakinan, nilai dan kebiasaan yang dipelajari oleh suatu kelompok masyarakat tertentu yang membantu mengarahkan perilaku konsumen.

Faktor-faktor budaya mempunyai pengaruh paling luas dan mendalam terhadap perilaku konsumen. Kultur (kebudayaan) adalah determinan paling fundamental dari keinginan dan perilaku seorang. Setiap kultur terdiri dari sub-sub kultur yang lebih kecil yang memberikan identifikasi dan sosialisasi yang lebih spesifik bagi para anggotanya. Sub kultur (sub budaya) mencakup kebangsaan, agama, kelompok ras, dan daerah geografis. Peranan lainnya yaitu kelas sosial, kelas sosial adalah divisi atau kelompok yang relatif homogen dan tetap dalam suatu masyarakat, yang tersusun secara hierarkis dan anggota-anggotanya memiliki nilai, minat, dan perilaku yang mirip (Abdullah \& Tantri, 2012).

Setiadi (2010) menyatakan bahwa faktor budaya memiliki pengaruh sebagai kebutuhan untuk menentukan perilaku apa saja yang dapat diterima semua luas dan mendalam terhadap perilaku konsumen di dalam pembelian. Peran budaya, sub budaya, dan kelas sosial konsumen sangatlah penting. Budaya berkembang karena kita hidup bersama orang lain di masyarakat. Hidup dengan orang lain menimbulkan anggota kelompok. Norma budaya dilandasi oleh nilai-nilai, keyakinan dan sikap yang dipegang oleh anggota kelompok masyarakat tertentu. Sistem nilai mempunyai dampak dalam perilaku membeli, misalnya orang yang memperhatikan masalah kesehatan akan membeli makanan yang tidak mengandung bahan yang merugikan kesehatannya.

Hasil penelitian yang dilakukan oleh Haliana (2009) meneliti tentang pengaruh budaya terhadap keputusan pembelian produk Mie Instan Merek Indomie mendapat kesimpulan bahwa secara parsial variabel faktor budaya berpengaruh positif signifikan terhadap keputusan pembelian produk merek Indomie.

$\mathrm{H}_{1}$ : Faktor budaya berpengaruh positif signifikan terhadap keputusan pembelian.

\section{Faktor Sosial}

Faktor sosial merupakan sekelompok orang yang secara bersama-sama mempertimbangkan secara dekat persamaan di dalam status atau penghargaan komunitas yang secara formal dan informal (Lamb et al, 2001). Faktor sosial dapat dilihat dari hubungan dengan teman, keluarga dan orang tua dalam mempengaruhi keputusan pembelian. Semakin tinggi hubungan dengan teman, keluarga dan orang tua, maka semakin tinggi keputusan konsumen untuk melakukan pembelian.

Para konsumen membeli berbagai produk tertentu berdasarkan kesadaran keanggotaan dalam kelas sosial yang menyangkut gaya hidup (kepercayaan, sikap, kegiatan, dan perilaku bersama) yang cenderung membedakan anggota setiap kelas dari anggota kelas sosial lainnya. Kelas sosial merupakan bentuk segmentasi yang hierarki dan alamiah, karena aspek hierarki kelas sosial begitu penting bagi pemasar dan produsen untuk menentukan konsumen mana yang akan menjadi sasaran produk yang telah diciptakan, apa untuk kelas yang lebih tinggi, menengah atau lebih rendah. Memang disini terlihat begitu nyata ketidakadilan dan jarak terhadap konsumen, namun itu semua merupakan segmentasi yang alamiah karena semua sudah terjadi dan tercipta dengan sendirinya (Effendi, 2016). 
Hasil penelitian yang dilakukan Nasution (2010), mengenai pengaruh faktor sosial terhadap keputusan pembelian produk Mie Instan merek Sedaap menyatakan bahwa faktor sosial secara positif dan signifikan berpengaruh terhadap pengambilan keputusan pembelian produk Mie Instan merek Sedaap.

$\mathrm{H}_{2}$ : Faktor sosial berpengaruh positif signifikan terhadap keputusan pembelian

\section{Faktor Pribadi}

Faktor pribadi merupakan cara mengumpulkan dan mengelompokkan kekonsistenan reaksi seorang individu terhadap situasi yang sedang terjadi (Lamb et al., 2001). Perilaku seseorang dalam membeli sesuatu juga dipengaruhi oleh faktor-faktor kepribadian dari konsumen yang bersangkutan. Faktor pribadi menggabungkan antara tatanan psikologis dan pengaruh lingkungan. Termasuk watak, dasar seseorang, terutama karakteristik dominan mereka. Meskipun kepribadian adalah salah satu konsep yang berguna dalam mempelajari perilaku konsumen, beberapa pemasar percaya bahwa kepribadian mempengaruhi jenis-jenis dan merek-merek produk yang dibeli. Faktor pribadi merupakan suatu keadaan dimana seseorang mempunyai sifat untuk bisa menentukan keputusannya sesuai dengan keinginannya tanpa ada paksaan dari pihak lain.

Meskipun disadari bahwa relatif sulit untuk mengetahui dan mengukur kepribadian konsumen, bukan berarti bahwa hal ini menyulitkan pemasar dan membuat pemasar tidak dapat berbuat apapun. Pada hakekatnya kepribadian adalah suatu kondisi kenyataan yang melekat pada konsumen. Adanya berbagai karakteristik kepribadian mengimplikasikan bahwa pemasar dapat mensegmentasikan pasarnya sesuai dengan karakteristik kepribadian. Faktor pribadi sangat mempengaruhi dalam keputusan pembelian, termasuk usia, umur dan daur hidupnya, pekerjaannya, kondisi ekonomi, gaya hidup, kepribadian dan konsep diri (Suryani, 2012).

Hasil penelitian yang dilakukan Darmawati et al. (2007) mengenai pengaruh pribadi terhadap keputusan pembelian produk Shar'e terhadap keputusan pembelian menyatakan bahwa faktor pribadi berpengaruh secara signifikan terhadap variabel keputusan pembelian produk Shar'e.

$\mathrm{H}_{3}$ : Faktor pribadi berpengaruh positif signifikan terhadap keputusan pembelian

\section{METODE PENELITIAN}

Penelitian ini adalah penelitian yang bersifat kuantitatif. Metode kuantitatif adalah suatu metode dengan menggunakan pendekatan secara ilmiah terhadap pengambilan keputusan manajerial maupun exsternal. Populasi dalam penelitian ini adalah mahasiswa Fakultas Ekonomi Universitas Sarjanawiyata Tamansiswa Yogyakarta. Teknik pengambilan sampel dalam penelitian ini menggunakan teknik accidental sampling yakni adalah mengambil responden sebagai sampel berdasarkan kebetulan, yaitu siapa saja yang secara kebetulan bertemu dengan peneliti dapat dijadikan sampel asalkan masih dalam populasi yaitu mahasiswa Fakultas Ekonomi Universitas Sarjanawiyata Tamansiswa (Sugiyono, 2008). 


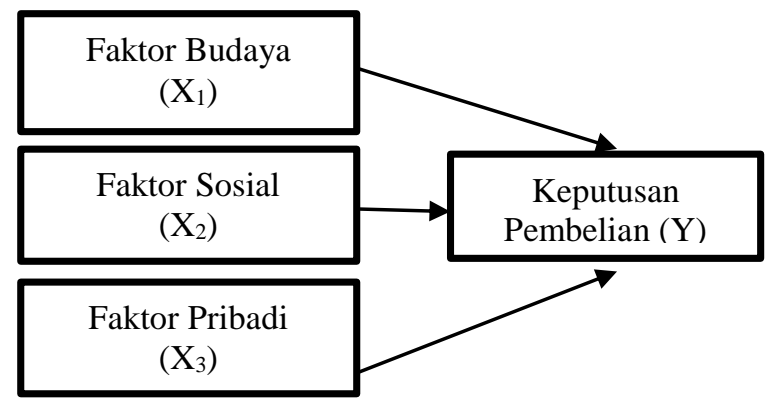

Gambar 1. Kerangka Pikir

\section{HASIL DAN PEMBAHASAN}

Berdasarkan pada hasil uji validitas dibuktikan bahwa semua butir pertanyaan dalam kuesioner dinyatakan valid. Hal ini karena $r$ hitung $>$ tabel. Berdasarkan uji reliabilitas dapat diketahui bahwa setiap butir pertanyaan dinyatakan reliabel. Hal ini karena setiap butir pertanyaan pada setiap variabel memiliki nilai Cronbach's Alpha diatas 0,6. Validitas dari variabel faktor budaya bahwa koefisien alpha cronbach $>0,6$ dinyatakan valid, variable faktor sosial koefisien Cronbach's Alpha > 0,6 dinyatakan valid, variabel faktor pribadi koefisien Cronbach's Alpha > 0.6 dinyatakan valid, dan variabel keputusan pembelian koefisien Cronbach's Alpha > 0,6.

Pada penelitian ini berdasarkan pengujian yang telah dilakukan maka analisis yang didapatkan yaitu data penelitian ini sudah lolos dalam pengujian asumsi klasik diantaranya yaitu normalitas, multikolinearitas dan heteroskedastisitas.

Tabel 1

Uji Regresi Linier Berganda

\begin{tabular}{|c|c|c|c|c|c|}
\hline \multirow{3}{*}{ Model } & \multicolumn{5}{|c|}{ Coefficients $^{\mathrm{a}}$} \\
\hline & \multicolumn{2}{|c|}{$\begin{array}{l}\text { Unstandardized } \\
\text { Coefficients }\end{array}$} & \multirow{2}{*}{$\begin{array}{c}\text { Standardized } \\
\text { Coefficients } \\
\text { Beta }\end{array}$} & \multirow[t]{2}{*}{$\mathrm{T}$} & \multirow[t]{2}{*}{ Sig. } \\
\hline & B & Std. Error & & & \\
\hline (Constant) & 1,871 & 1,273 & & 1,470 & ,145 \\
\hline FaktorBudaya & 263 &, 120 & 155 & 2,200 &, 030 \\
\hline Faktor Sosial &,- 132 &, 110 &,- 088 & $-1,201$ & ,233 \\
\hline Faktor Pribadi & 866 & 069 & 885 & 12,602 &, 000 \\
\hline \multicolumn{6}{|l|}{ a. Dependent } \\
\hline
\end{tabular}

Sumber: Data primer diolah, 2019

Model 2L $=\mathrm{b} 1 \mathrm{~T}+\mathrm{b} 2 \mathrm{Q}+\mathrm{b} 3 \mathrm{BE}+\mathrm{b} 4 \mathrm{~S}+\mathrm{ei}$

$=-0,055 \mathrm{~T}+-0,021 \mathrm{Q}+0,417 \mathrm{BE}+0,258 \mathrm{~S}+\mathrm{ei}$

$=-0,055 \mathrm{~T}+-0,021 \mathrm{Q}+0,417 \mathrm{BE}+0,258 \mathrm{~S}$

Apabila setiap terjadi kenaikan pada faktor budaya maka akan diikuti kenaikan keputusan pembelian sebesar 0,155 dan variabel lain diasumsikan tetap. Semakin baik pada faktor budaya maka semakin pula tinggi keputusan pembelian. Apabila setiap terjadi penurunan pada faktor sosial maka akan diikuti penurunan keputusan pembelian sebesar - 
0,088 dan variabel lain diasumsikan tetap. Semakin menurun pada faktor sosial maka semakin menurun pula keputusan pembelian. Apabila setiap terjadi kenaikan pada faktor pribadi maka akan diikuti kenaikan keputusan pembelian sebesar 0,885 dan variabel lain diasumsikan tetap. semakin baik faktor pribadi maka semakin tinggi pula keputusan pembelian.

Berdasarkan Uji t penelitian ini menunjukkan bahwa variabel faktor budaya (X1) berpengaruh positif signifikan terhadap keputusan pembelian. Hal ini dibuktikan dengan melihat hasil tingkat signifikansi $0,030 / 2=0,015<0,05$, dengan demikian hipotesis yang pertama bahwa faktor budaya dinyatakan diterima. Variabel sosial (X2) tidak berpengaruh positif signifikan terhadap keputusan pembelian, Hal ini dibuktikan dengan melihat hasil tingkat signifikansi 0,233/2=0,1165 >0,05, dengan demikian hipotesis yang kedua bahwa faktor sosial dinyatakan ditolak. Sedangkan variabel faktor pribadi (X3) berpengaruh positif signifikan terhadap keputusan pembelian. Hal ini dibuktikan dengan melihat hasil tingkat signifikansi $0,000 / 2=0<0,05$, dengan demikian hipotesis yang ketiga bahwa faktor pribadi dinyatakan diterima.

Tabel 2

Koefisien Determinasi

\begin{tabular}{lccc}
\hline Model & R $\quad$ R Square & $\begin{array}{c}\text { Model Summary } \\
\text { Adjusted R } \\
\text { Square }\end{array}$ & $\begin{array}{c}\text { Std. Error of the } \\
\text { Estimate }\end{array}$ \\
\hline $1 \quad, 189^{\mathrm{a}}$ &, 036 &, 006 & 1,97950 \\
a. Predictors: (Constant), Faktor Pribadi, Faktor Budaya, Faktor Sosial \\
b. Dependent Variable: Abs_res
\end{tabular}

Dari perhitungan tabel diatas diperoleh nilai Adjusted $\mathrm{R}^{2}=00,6$, hal ini menunjukkan bahwa variasi keputusan pembelian yang menunjukkan variabel bebas secara bersama-sama mempengaruhi variabel tidak bebas sebesar $0,006 \%$. Sisanya 99,4 \% dijelaskan oleh variabel diluar model penelitian ini antara lain produk, harga, tempat, promosi.

\section{KESIMPULAN DAN SARAN}

Berdasarkan uji t atau uji parsial variabel faktor budaya diterima berpengaruh positif signifikan terhadap keputusan pembelian rokok Sampoerna Mild pada mahasiswa Fakultas Ekonomi Sarjanawiyata Tamansiswa Yogyakarta. Hasil ini dibuktikan dengan hasil pengujian regresi dengan tingkat signifikansi sebesar 0,030/2=0,015 $<0,05$ Maka faktor budaya tidak berpengaruh positif signifikan terhadap keputusan pembelian rokok Sampoerna Mild.

Variabel faktor sosial budaya tidak berpengaruh positif signifikan terhadap keputusan pembelian rokok Sampoerna Mild pada mahasiswa Fakultas Ekonomi Sarjanawiyata Tamansiswa Yogyakarta. Hasil ini dibuktikan dengan hasil pengujian regresi dengan tingkat signifikansi sebesar $0,233 / 2=0,1165>0,05$ Maka faktor sosial tidak berpengaruh positif signifikan terhadap keputusan pembelian rokok Sampoerna Mild. 
Variabel faktor pribadi berpengaruh positif signifikan terhadap keputusan pembelian rokok Sampoerna Mild pada mahasiswa Fakultas Ekonomi Sarjanawiyata Tamansiswa Yogyakarta. Hasil ini dibuktikan dengan hasil pengujian regresi dengan tingkat signifikansi sebesar $0,000 / 2=0>0,05$ Maka faktor pribadi berpengaruh positif signifikan terhadap keputusan pembelian rokok Sampoerna Mild.

Saran bagi perusahaan: Faktor budaya berpengaruh positif terhadap keputusan pembelian. Maka perusahaan diharapkan untuk meningkatkan dan mempertahankan indikator yang ada dalam faktor budaya yaitu budaya, sub budaya dan kelas sosial. Jika indikator tersebut meningkat maka keputusan pembelian juga akan meningkat.

Faktor pribadi berpengaruh positif signifikan terhadap keputusan pembelian. maka perusahaan diharapkan untuk meningkatkan dan mempertahankan indikator yang ada dalam faktor pribadi yaitu usia, pekerjaan, situasi ekonomi, gaya hidup dan kepribadian. jika indikator tersebit meningkat maka keputusan pembelian juga akan meningkat. Saran bagi akademisi: dapat dijadikan sebagai bahan pemikiran, pertimbangan atau bahan referensi mengenai keputusan pembelian dan mengembangkannya lebih lanjut.

\section{DAFTAR PUSTAKA}

Abdullah, T. dan Tantri, F. (2012). Manajemen Pemasaran, Jakarta: Rajagrafindo Persada. Samsuridjal, D. (2009). Raih Kembali Kesehatan Mencegah Berbagai Penyakit Hidup Sehat Untuk Keluarga, Jakarta:Kompas

Darmawati, D., Subekti, B., Setyawati, S. M., \& Sumarsono, S. (2018). Analisis Pengaruh Kebudayaan, Sosial, Kepribadian, dan Psikologis terhadap Keputusan Pembelian Shar'e (Survei pada Nasabah Bank Muamalat Indonesia Cabang Purwokerto). Performance: Jurnal Personalia, Financial, Operasional, Marketing dan Sistem Informasi, 6(1), 16-32.

Effendi, Usman, (2016). Psikologi Konsumen, Jakarta: PT. Raja Grafindo Persada.

Haliana, Novel, (2009). Analisis Faktor-Faktor Yang Mempengaruhi Konsumen Dalam Pengambilan Keputusan Pembelian Produk Mie Instan Merek Indomie, Jurnal.

Kumar, A., Shankar, R., \& Aljohani, N. R. (2020). A big data driven framework for demanddriven forecasting with effects of marketing-mix variables. Industrial marketing management, 90, 493-507.

Lamb, C. W., Hair, J. F., \& McDaniel, C. D. (2001). Pemasaran. Thomson Learning.

Nasution, R.A. (2010), Analisis Faktor-faktor Yang Mempengaruhi Konsumen Dalam Pengambilan Keputusan Pembelian Produk Mie Instan Merek Sedaap Pada Mahasiswa Fakultas Ekonomi Program Ekstensi Univeritas Sumatera Utara, Skripsi Fakultas Ekonomi Universitas Sumatera Utara.

Rahmad, R., Sabri, S., \& Nasfi, N. (2020). Pengaruh Faktor Pribadi, Organisasi, dan Non Organisasi terhadap Komitmen Karyawan pada PT. PLN Area Bukittinggi. Jurnal Apresiasi Ekonomi, 8(1), 142-152.

Sari, R. K., Zulaikhah, S. T., \& Livana, P. H. (2019). Perbedaan Pengetahuan Perokok Aktif dan Perokok Pasif Tentang Bahaya Rokok. Jurnal Ilmiah Permas: Jurnal Ilmiah STIKES Kendal, 9(2), 85-94.

Schiffman, L.G., \& Kanuk, L.L. (2010). Consumer Behaviour $\left(10^{\text {th }}\right.$ ed). New Jersey, Pearson. Prentice Hall.

Setiadi, Nugroho J, (2010), Perilaku Konsumen Konsep dan Implikasi untuk Strategi dan Penelitian Pemasaran, Jakarta: Kencana. 
Supardi, (2005), Metodologi Penelitian Ekonomi dan Bisnis, Yogyakarta: UII Press Yogyakarta.

Sugiyono, (2008), Metode Penelitian Kuantitatif Kualitatif dan R\&D, Bandung: Alfabeta.

Suryani, Tatik. (2012), Perilaku Konsumen Implikasi pada Strategi Pemasaran, Yogyakarta: Graha Ilmu.

Uguy, J. M., Nelwan, J. E., \& Sekeon, S. A. (2019). Kebiasaan Merokok Dan Kejadian Hipertensi Di Wilayah Kerja Puskesmas Molompar Belang Kecamatan Belang Kabupaten Minahasa Tenggara Tahun 2018. KESMAS, 8(1), 44-48.

Vu, H. N. D., Nielsen, M. R., \& Jacobsen, J. B. (2020). Reference group influences and campaign exposure effects on rhino horn demand: Qualitative insights from Vietnam. People and Nature, 2(4), 923-939.

Wahyuni, D., \& Bachri, S. (2020). Pengaruh Faktor Pribadi terhadap Keputusan Konsumen Berkunjung ke Nextdoor Café di Palu. Jurnal Ilmu Manajemen Universitas Tadulako, 6(3), 261-271. 